\title{
BRPKM
}

Buletin Riset Psikologi dan Kesehatan Mental

http://e-journal.unair.ac.id/index.php/BRPKM

e-ISSN: 2776-1851

ARTIKEL PENELITIAN

\section{Pengaruh Dukungan Sosial Teman Sebaya terhadap Tingkat Stres Mahasiswa yang Mengerjakan Skripsi}

\author{
MUHAMMAD RAFI RAHADIANSYAH \& ACHMAD CHUSAIRI* \\ Fakultas Psikologi Universitas Airlangga
}

\begin{abstract}
ABSTRAK
Tujuan penelitian ini adalah untuk mengetahui pengaruh dukungan sosial teman sebaya terhadap tingkat stres mahasiswa yang mengerjakan skripsi. Penelitian ini menggunakan metode pendekatan kuantitatif dengan metode survei yang dilakukan kepada 164 orang mahasiswa yang sedang menulis skripsi. Pengumpulan data menggunakan skala dukungan sosial teman sebaya untuk mengukur seberapa besar dukungan sosial teman sebaya yang dimiliki seorang mahasiswa dan menggunakan skala tingkat stres untuk mengukur tingkat stres mahasiswa yang sedang mengerjakan skripsi. Hasil analisis data dengan regresi linear sederhana menunjukkan bahwa tidak terdapat pengaruh yang signifikan antara dukungan sosial teman sebaya dengan tingkat stres pada mahasiswa yang mengerjakan skripsi $\left(R^{2}=0,019 ; F(164)=3,171 ; p>0,05\right)$.
\end{abstract}

Kata kunci: dukungan sosial, mahasiswa, skripsi, teman sebaya, tingkat stres

\section{ABSTRACT}

This research aims to find out the influence of social peer support to the stress level of college students who are working on the thesis. This research uses a quantitative approach with a survey method conducted to 164 college students who are writing on the thesis. Questionnaires in this research are scale of social peer support was used to measure how much the social peer support who their college students have and uses scale of stress level was used to measure college students stress level who working on the thesis. The result of this research with simple regression linear showed that social peer support does not significantly have an influence to the stress level of college students who working on the thesis $\left(R^{2}=0,019 ; F(164)=3,171 ; p>0,05\right)$.

Keywords: college student, peer, social support, stress level, thesis

Buletin Penelitian Psikologi dan Kesehatan Mental (BRPKM), 2021, Vol. 1(2), 1290-1297

*Alamat korespondensi: Fakultas Psikologi Universitas Airlangga, Kampus B Universitas Airlangga Jalan

Airlangga 4-6 Surabaya 60286. Surel: achmad.chusairi@psikologi.unair.ac.id

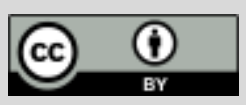

Naskah ini merupakan naskah dengan akses terbuka di bawah ketentuan the Creative Common Attribution License (CC-BY-4.0) (http://creativecommons.org/licenses/by/4.0), sehingga penggunaan, distribusi, reproduksi dalam media apapun atas artikel ini tidak dibatasi, selama sumber aslinya disitir dengan baik. 


\section{PENDAHULUAN}

Masa dewasa awal merupakan masa transisi dari masa remaja, yang menjalani kehidupan dengan penuh ketergantungan, menuju masa dewasa yang lebih mandiri dan bertanggung jawab. Pada usia tersebut, dalam kehidupan sehari-hari, mahasiswa perlu berpikir cepat, tanggap dan peka terhadap apa yang terjadi terjadi di lingkungan sekitarnya, yang salah satunya yang dapat menimbulkan masalah yaitu tugas akhir atau skripsi. Mengatur jadwal untuk mengejar deadline yang berkaitan dengan skripsi, seperti melakukan penelitian lapangan, pemikiran ilmiah dan penulisan. Mahasiswa tidak hanya harus menyelesaikan skripsi setelah lulus, Mereka juga harus hidup lebih mandiri untuk menentukan masa depannya (Rohmah, 2017).

Skripsi harus mampu memberikan kontribusi nyata bagi pencarian kebenaran, yang berarti berusaha mendapatkan sesuatu seperti kontribusi nyata untuk membuktikan kebenaran. Padahal, dalam keadaan normal, perjalanan belajar mahasiswa saat menulis skripsi akan menjadi lambat atau terhambat. Mutadin (2004 dalam Dewi, 2018) mengatakan bahwa beberapa hal yang menjadi kendala dalam pengerjaan skripsi, antara lain: pengerjaan skripsi yang membosankan, proses pengumpulan data yang lama, kesulitan dalam menuliskan ide dalam bentuk tulisan, kesulitan dalam mengalokasikan waktu antara menulis skripsi dengan kegiatan lain misalnya bekerja dan kurangnya keterampilan berbahasa inggris.

Penelitian yang dilakukan oleh Giyarto (2018) melalui metode wawancara menunjukkan bahwa dari ke 4 responden mereka hampir mengalami hal yang sama. Permasalahan yang membuat mereka stres ketika mengerjakan skripsi yaitu dosen pembimbing yang sulit dihubungi, masih banyak mendapat revisi, sulit mencari buku dan jurnal. Dari hasil penelitian tersebut, permasalahan yang mereka alami akan berdampak pada kondisi biologis, psikologis, emosi, maupun perilaku. Contohnya ketika di wawancara mereka menjadi kurang fokus seperti melamun, menjadi lebih sensitif dan mudah marah, gelisah dan cepat lelah.

Penelitian yang dilakukan oleh Zakaria (2017) menunjukkan bahwa proporsi mahasiswa kategori ringan yang stres saat mengerjakan skripsi adalah 8,5\%, kemudian kategori sedang 86,5\%, dan kategori berat 5\%. Dilihat dari hasil penelitian ini, dari segi usia adanyat tekanan sosial berupa opini negatif dari masyarakat, dengan bertambahnya usia, tekanan kelulusan dan tuntutan dari orang tua juga akan mempengaruhi citra diri mahasiswa. Ditinjau dari lamanya pengerjaan skripsi, semakin lama pengerjaan skripsi maka semakin besar pula tingkat stres mahasiswa dilihat dari persentase kategori stres berat yang semakin besar. Hal ini dikarenakan semakin lama pengerjaan skripsi berlangsung dan penundaan akan meningkatkan tingkat stres.

Menurut Lazarus dan Folkman (1984 dalam Gamayanti dkk., 2018), stres berhubungan dengan interaksi antara manusia dengan lingkungan, sebagai beban yang dirasa melebihi kekuatannya. Menurut Handoyo (2001 dalam Gamayanti dkk., 2018), stres dapat dinyatakan sebagai tuntutan eksternal yang dihadapi seseorang, dan tuntutan tersebut sebenarnya berbahaya atau menimbulkan masalah. Abdulghani (2008 dalam Gamayanti dkk., 2018) mengungkapkan bahwa stres dapat memiliki efek positif atau negatif. Ketika stres tidak melebihi kemampuan individu, stres akan berdampak positif. Dampak positif stres pada mahasiswa antara lain tantangan untuk mengembangkan dan memupuk kreativitas. Dampak negatif dari stres dapat berupa kesulitan berkonsentrasi (perhatian) selama di kelas, bahkan ketika mengikuti proses bimbingan skripsi dengan dosen pembimbing, penurunan minat pada apa yang biasanya individu lakukan, penurunan motivasi bahkan mempengaruhi perilaku untuk mengurangi stres. 
Gejala stres secara umum terbagi menjadi tiga aspek, pertama gejala fisik yaitu gangguan tidur dan perubahan nafsu makan. Gejala emosional berupa perubahan suasana hati, mudah marah, cemas dan kurang semangat untuk beraktivitas. Gejala tidak mampu berkonsentrasi, bingung dan meningkatnya pikiran negatif Astiko (2013 dalam Gamayanti dkk., 2018).

Menurut Sarason dkk, dukungan sosial dapat menghilangkan efek stres, dapat mengatasi peristiwa stres, dan mengurangi potensi stres yang menyebabkan masalah kesehatan (Rohmah, 2017). Dukungan sosial dapat ditafsirkan sebagai kenyamanan, perawatan, ataupun bantuan yang diterima oleh individu dari orang lain yang dapat merujuk pada individu atau kelompok. Dukungan sosial yang disediakan dapat membuat orang merasa dicintai, dihargai, dan menjadi bagian dari jejaring sosial (Sarafino \& Smith, 2014). Dukungan sosial dapat berasal dari pasangan, keluarga, teman, masyarakat, teman satu kelompok, teman kerja, dan atasan (Taylor, 2009). Secara umum, mahasiswa menghabiskan lebih banyak waktu dengan teman sebaya pada tahap remaja, sehingga peran teman sebaya sebagai sumber dukungan emosional sangat penting Papalia dkk. (2008 dalam Dinata \& Supriyadi, 2019).

Menurut Taylor (2003) dukungan sosial dibagi menjadi 4 jenis yaitu: 1) dukungan instrumental—ketika individu dalam tekanan, dukungan diberikan dalam bentuk fasilitas atau bantuan langsung, seperti jasa, bantuan keuangan, atau barang; 2) dukungan informasi — ada informasi tentang pengobatan yang dapat dilakukan individu, nasehat, informasi untuk kesadaran atau bimbingan untuk memecahkan masalah ketika orang tersebut sedang stres; 3) dukungan emosional—membuat orang percaya bahwa mereka adalah orang yang berharga, mengungkapkan empati dan kepedulian terhadap individu dapat membuat mereka, merasa nyaman, tenang dan dicintai di bawah situasi yang penuh tekanan; 4) dukungan penghargaan—memberikan dukungan dalam bentuk penghargaan positif, penghargaan individu atas usaha mereka dan memperkuat tindakan positif individu dalam kondisi stres.

Penelitian yang dilakukan oleh Dwijayanti (2018) menemukan bahwa r=0,690 dengan nilai signifikansi sebesar 0,000 $(\mathrm{p}<0,05)$ artinya semakin besar dukungan sosial teman sebaya maka semakin kecil kecemasan mengerjakan tugas akhir/skripsi, dengan dukungan sosial teman sebaya berkontribusi terhadap kecemasan mengerjakan tugas akhir/skripsi sebesar 48\%. Dari hasil tersebut, dukungan sosial kembali berperan dalam pemecahan masalah, seperti memberikan nasehat, saran, motivasi dan peminjaman buku serta mengurangi emosi negatif karena masalah yang sedang dihadapi, yang jika tidak didapatkan oleh mahasiswa yang mengerjakan skripsi maka akan memperburuk perasaan cemas dan berakhir menjadi stres.

Penelitian yang dilakukan oleh Saputra \& Palupi (2020) menemukan koefisien korelasi sebesar 0,760 yang berarti ada hubungan antara dukungan sosial dengan kesejahteraan psikologis pada mahasiswa tingkat akhir yang sedang mengerjakan skripsi di Universitas Airlangga. Dari hasil tersebut bisa dikatakan bahwa jika dukungan sosial tinggi maka kesejahteraan psikologis yang akan dialami individu juga tinggi. Mahasiswa yang mengerjakan skripsi memiliki beberapa sumber stressor yang membuat individu mengalami masalah, tingginya dukungan sosial yang diterima individu dapat meningkatkan kesejahteraan psikologis. Meningkatnya kesejahteraan ini nantinya dapat mengurangi stres yang dialami individu.

Pada dasarnya manusia adalah makhluk sosial dan membutuhkan orang lain dalam hidupnya, bahkan jika seseorang mengalami tekanan yang dapat menyebabkan stres. Dukungan sosial membuat seseorang merasa nyaman, didukung, dicintai ketika dalam kondisi stres, membangkitkan rasa harga diri, kompeten dan bernilai. Membuat individu merasa mampu menghadapi rintangan ketika melakukan sesuatu. Seperti halnya mahasiswa yang menulis skripsi, dukungan sosial dapat 
memungkinkan mereka untuk mengatasi stres, menurunkan tingkat stres dan melakukan berbagai upaya untuk mencapai sasaran atau tujuan.

Di masa pandemi seperti sekarang, banyak teman yang pulang kampung atau terisolir di rumah akibat pemberlakuan PSBB. Di sini, peran dukungan sosial teman sebaya seharusnya lebih dibutuhkan apabila dibandingkan dengan yang lain (orang tua, pacar, dll) karena mahasiswa akan menghabiskan lebih banyak waktu dengan teman sebaya yang dapat saling memahami. Di lain sisi, teman sebaya juga dapat digunakan sebagai sumber afeksi, simpati, pemahaman, dan bimbingan moral, tempat bereksperimen, dan lingkungan dimana mereka dapat memperoleh otonomi dan kemandirian dari orang tua mereka.

Berdasarkan permasalahan yang sudah dipaparkan di atas dan juga penelitian sebelumnya, hal inilah yang mendorong peneliti mengangkat isu dampak dukungan sosial teman sebaya terhadap tingkat stres mahasiswa yang mengerjakan skripsi. Ada banyak penelitian sebelumnya tentang dukungan sosial dan tingkat stres, namun penelitian mengenai pengaruh dukungan sosial teman sebaya terhadap tingkat stres masih sedikit. Oleh karena itu peneliti sangat tertarik dengan penelitian ini, terutama ingin mengetahui seberapa besar pengaruh dukungan sosial teman sebaya bagi mahasiswa yang mengerjakan skripsi dalam menghadapi tingkat stres.

\section{METODE}

\section{Desain Penelitian}

Pada penelitian ini, peneliti menggunakan pendekatan kuantitatif dengan prosedur pengambilan data secara survei serta menggunakan kuesioner sebagai alat dalam mengumpulkan data, guna mengetahui pengaruh dukungan sosial teman sebaya terhadap tingkat stres pada mahasiswa yang sedang mengerjakan skripsi. Dalam studi kuantitatif survei yang dilakukan, penelitian ini dilakukan dengan menyebarkan kuesioner pada partisipan yang berisi alat ukur dukungan sosial teman sebaya yang diadopsi dari penelitian sebelumnya serta alat ukur tingkat stres yang diadaptasi dari penelitian sebelumnya dan dirombak oleh peneliti menyesuaikan dengan kondisi penelitian, yang kemudian divalidasi oleh peneliti. Data dari responden tersebut selanjutnya dianalisis menggunakan teknik analisis regresi linear sederhana.

\section{Partisipan}

Partisipan pada penelitian ini adalah mahasiswa aktif baik laki-laki maupun perempuan yang sedang mengerjakan skripsi. Penentuan jumlah sampel partisipan dalam penelitian ini menggunakan metode non-probability sampling karena populasi dalam penelitian ini tidak diketahui dengan jelas jumlahnya dan dengan teknik accidental sampling agar peneliti dapat menggunakan sampel siapapun partisipan yang memenuhi kriteria partisipan. Penentuan besar sampel minimal pada penelitian ini menggunakan bantuan aplikasi $G^{*}$ Power 3.1.9.2 dengan statistical power sebesar 0,80 dan effect size sebesar 0,25 sehingga jumlah sampel minimal yang harus didapat yaitu sebesar 128 orang. Jumlah partisipan dalam penelitian ini sebesar 164 orang $\left(\mathrm{N}_{\text {laki-laki }}=40 ; \mathrm{N}_{\text {perempuan }}=124\right)$ yang merupakan mahasiswa aktif yang sedang dalam masa pengerjaan skripsi dari total 69 Perguruan Tinggi Negeri dan Swasta di seluruh Indonesia. Sebelum pengisian kuesioner, partisipan diberikan informed consent terlebih dahulu sebagai bentuk persetujuan dari partisipan dalam mengikuti penelitian ini. 


\section{Pengukuran}

Pada penelitian ini, pengumpulan data dilakukan menggunakan skala dukungan sosial teman sebaya yang diadopsi dari penelitian yang dilakukan oleh Rohmah (2017) berdasarkan dimensi dukungan sosial oleh Taylor (2003), yaitu dukungan instrumental, dukungan informasi, dukungan emosional, dan dukungan penghargaan, dengan terdiri dari 30 item total setelah dilakukan uji coba dan disajikan berupa skala likert dengan 5 pilihan jawaban" (1="sangat tidak setuju", 5="sangat setuju), serta alat ukur tingkat stres yang diadaptasi dari penelitian sebelumnya yang dilakukan oleh Sulistyowati (2016) kemudian dirombak oleh peneliti menyesuaikan dengan kondisi penelitian berdasarkan dimensi tingkat stres menurut Maramis (2009 dalam Sulistyowati, 2016) yaitu gejala fisik, gejala psikologis, dan gejala perilaku, dengan terdiri dari 23 item total setelah dilakukan uji coba dan disajikan berupa skala likert dengan 5 pilihan jawaban (1="sangat tidak setuju", 5="sangat setuju). Hasil analisis reliabilitas dengan teknik Cronbach's alpha untuk masing-masing skala dukungan sosial teman sebaya dan skala tingkat stres, yaitu sebesar 0,874 dan 0,791 yang artinya kedua alat ukur tersebut reliabel dan memiliki konsistensi yang tinggi apabila digunakan berulang kali dalam suatu penelitian.

\section{Analisis Data}

Pada penelitian ini, analisis data dilakukan dengan menggunakan teknik analisis regresi linear sederhana dengan bantuan aplikasi IBM SPSS Statistic 25 for Windows.

\section{HASIL PENELITIAN}

\section{Uji Deskriptif}

Uji deskriptif penelitian ini menggunakan partisipan sebanyak 164 orang dengan nilai terendah pada variabel dukungan sosial teman sebaya sebesar 91 dan variabel tingkat stres sebesar 59, sedangkan nilai tertinggi pada variabel dukungan sosial teman sebaya sebesar 142 dan variabel tingkat stres sebesar 110. Nilai mean variabel dukungan sosial teman sebaya sebesar 116,98 sedangkan untuk variabel tingkat stres sebesar 82,10. Berdasarkan norma kategorisasi, sebagian besar partisipan penelitian memiliki tingkat dukungan sosial teman sebaya yang dikategorikan sedang, yaitu sebesar $64,6 \%(\mathrm{~N}=106)$, serta memiliki tingkat stres dalam kategori sedang yaitu sebesar $61,6 \%(\mathrm{~N}=101)$.

\section{Uji Hipotesis}

Setelah dilakukan uji asumsi dan hasil dari uji asumsi dapat terpenuhi, maka peneliti melakukan uji hipotesis yaitu uji regresi yang dilakukan untuk mengetahui arah dan kekuatan pengaruh yang linear dari kedua variabel. Uji regresi dilakukan menggunakan teknik analisis regresi linear sederhana. Model penelitian diketahui cocok dalam menjelaskan data $\left(R^{2}=0,019 ; F(164)=3,171 ; p>0,05\right)$ dan varians prediktor dapat menjelaskan $1,9 \%$ dari varians variabel tingkat stres. Dukungan sosial teman sebaya $(B=-0,117 ; 95 \%$; $S E=0,066 ; t=-1781 ; p>0,05)$ berkorelasi negatif dan cukup lemah dalam menjelaskan tingkat stres pada mahasiswa yang sedang mengerjakan skripsi, sehingga diketahui bahwa tidak terdapat pengaruh yang signifikan antara variabel dukungan sosial teman sebaya dan variabel tingkat stres.

\section{DISKUSI}

Berdasarkan hasil dari analisis regresi linear sederhana yang mengamati pengaruh dukungan sosial teman sebaya terhadap tingkat stres, diketahui bahwa dukungan sosial tidak berpengaruh secara 
signifikan terhadap tingkat stres pada mahasiswa yang sedang mengerjakan skripsi $\left(R^{2}=0,019\right.$; $F(164)=3,171 ; p>0,05)$. Hal ini menunjukkan bahwa dukungan sosial dari teman sebaya bukanlah satusatunya faktor yang mempengaruhi tingkat stres mahasiswa yang sedang mengerjakan skripsi, karena masih banyak faktor yang dapat mempengaruhi tingkat stres mahasiswa ketika mengerjakan skripsi, antara lain keadaaan ekonomi, kondisi fisik, karakteristik kepribadian, keuletan (perseverance), locus of control dan strategi koping (Rahmawan \& Selviana, 2021).

Hasil norma kategorisasi penelitian pada data dukungan sosial teman sebaya menunjukkan bahwa mayoritas partisipan dalam penelitian ini memiliki dukungan sosial pada tingkat yang sedang. Sarafino \& Smith (2014) mengungkapkan bahwa dukungan sosial mengacu pada bantuan yang diberikan seseorang, sehingga mahasiswa yang mengerjakan skripsi terkadang mendapatkan bantuan dari teman sebayanya ketika memecahkan masalah. Hal ini dapat dijelaskan bahwa mahasiswa yang mengerjakan skripsi hanya sesekali saja mendapat dukungan sosial untuk memastikan ada orang yang dapat dipercaya untuk membantunya, mendapatkan pengakuan atas kemampuannya, mendapat penghargaan dari orang lain, dan hanya sesekali pula mendapatkan informasi, saran atau nasehat yang diperlukan dalam memenuhi kebutuhan dan mengatasi permasalahan khususnya saat mengerjakan skripsi.

Sedangkan untuk hasil norma kategorisasi penelitian pada data tingkat stres menunjukkan bahwa sebagian peserta partisipan dalam penelitian ini memiliki tingkat stres yang sedang. Menurut Potter \& Perry (2015 dalam Afryan dkk., 2019) individu yang mengalami tingkat stres sedang dan tinggi biasanya mengalami situasi seperti mempunyai perselisihan dengan rekan kerja, beban kerja yang berlebihan, kehilangan anggota keluarga atau jauh dengan keluarga, kesulitan finansial yang berkepanjangan dan penyakit fisik yang jangka panjang, yang berlangsung selama beberapa hari hingga berbulan-bulan. Stres ini dapat menyebabkan iritabilitas, reaksi berlebihan, kesulitan istirahat, pesimisme yang berlebihan, depresi dan mudah putus asa (Afryan dkk., 2019).

\section{SIMPULAN}

Penelitian ini berfokus pada pengaruh dukungan sosial teman sebaya terhadap tingkat stres mahasiswa yang sedang mengerjakan skripsi. Berdasarkan hasil analisis data penelitian yang telah dilakukan, diketahui bahwa dukungan sosial dari teman sebaya tidak berpengaruh signifikan terhadap tingkat stres pada mahasiswa yang sedang mengerjakan skripsi.

Penelitian ini diharapkan dapat memberikan manfaat bagi penelitian selanjutnya, mahasiswa dan perguruan tinggi. Dari hasil penelitian ini, peneliti meyakini untuk penelitian selanjutnya diharapkan bisa lebih menyempurnakan konsep dan teori yang digunakan dalam penelitian, memilih dan menyesuaikan alat ukur yang digunakan agar sesuai dengan kondisi penelitian yang dilakukan khususnya untuk variabel dukungan sosial, terlebih memperhatikan sumber-sumber dukungan sosial lainnya seperti dukungan sosial dari keluarga, orang tua, dll., dan mengusulkan penambahan variabel lain yang lebih besar pengaruhnya terhadap tingkat stres pada mahasiswa yang sedang mengerjakan skripsi.

Dari hasil penelitian ini, peneliti menghasilkan saran kepada mahasiswa agar lebih mempersiapkan diri untuk mengerjakan skripsi seperti menambah ilmu penelitian, mencari referensi yang dapat dipercaya saat menyusun skripsi, mengatur waktu dengan tepat serta dapat memperhatikan faktor apa saja yang paling mudah membuat individu stres agar mengetahui strategi yang tepat untuk mengatasi stres di masa depan dan diharapkan melakukan lebih banyak hal positif, mengatur waktu dengan baik untuk menghindari prokrastinasi dan mampu mengendalikan emosi negatif sehingga proses pengerjaan skripsi tidak terhambat oleh stres yang timbul karena emosi negatif. Selain itu, peneliti memberikan 
saran bagi perguruan tinggi untuk dapat dijadikan referensi bagi penelitian yang akan datang serta menjadi tolok ukur dan teknik dalam melakukan pendekatan kepada mahasiswa untuk meminimalisir tingkat stres yang dirasakan oleh mahasiswa.

\section{UCAPAN TERIMAKASIH}

Dengan hormat, diucapkan terima kasih kepada Dr. Achmad Chusairi, MA., selaku dosen pembimbing skripsi, Bapak Siswadi dan Ibu Sulistyaning Rahayu selaku kedua orang tua penulis, Faa'iz Rahadian Akbar selaku kakak dari Penulis, dan Dieva Adelia Salsabila beserta seluruh sahabat terdekat penulis yang tidak dapat disebutkan satu persatu dalam membantu proses pengerjaan penelitian ini.

\section{DEKLARASI POTENSI TERJADINYA KONFLIK KEPENTINGAN}

Muhammad Rafi Rahadiansyah dan Achmad Chusairi tidak bekerja, menjadi konsultan, memiliki saham, atau menerima dana dari perusahaan atau organisasi manapun yang mungkin akan mengambil untung dari diterbitkannya naskah ini.

\section{PUSTAKA ACUAN}

Afryan, M., Saputra, O., \& Liliswanti, R. (2019). Hubungan Tingkat Stres Terhadap Motivasi Mahasiswa Dalam Menyelesaikan Skripsi Pada Mahasiswa Tingkat Akhir di Fakultas Kedokteran Universitas Lampung. Jurnal Kedokteran, 6(1), 63-67.

Dinata, I.G.D.A., \& Supriyadi. (2019). Hubungan kontrol diri , beban kerja dan dukungan sosial teman sebaya terhadap prokrastinasi akademik pada mahasiswa Universitas Udayana yang bekerja part time. Psikologi Udayana, 103-115.

Dewi, N. R. (2018). KESULITAN MAHASISWA SEMESTER AKHIR DALAM MENYUSUN SKRIPSI. (Skripsi, UIN Sulthan Thaha Saifuddin Jambi).

Dwijayanti, I. P. (2018). HUBUNGAN ANTARA DUKUNGAN SOSIAL TEMAN SEBAYA DENGAN KECEMASAN MENGERJAKAN TUGAS AKHIR/SKRIPSI PADA MAHASISWA UKSW. In Skripsi.

Gamayanti, W., Mahardianisa, M., \& Syafei, I. (2018). Self Disclosure dan Tingkat Stres pada Mahasiswa yang sedang Mengerjakan Skripsi. Psympathic: Jurnal Ilmiah Psikologi, 5(1), 115-130. https://doi.org/10.15575/psy.v5i1.2282

Giyarto, G. (2018). Stres pada mahasiswa tingkat akhir fakultas psikologi universitas muhammadiyah surakarta dalam mengerjakan skripsi. (Skripsi, Universitas Muhammadiyah Surakarta).

Rahmawan, F. R., \& Selviana. (2021). Hubungan Adversity Quotient dan Dukungan Sosial Teman Sebaya dengan Tingkat Stres Mahasiswa yang Menyelesaikan Skripsi. Jurnal IKRA-ITH Humaniora, 5(1), 19.

Rohmah, Q. (2017). PENGARUH DUKUNGAN SOSIAL TEMAN SEBAYA TERHADAP STRES PADA MAHASISWA YANG MENGERJAKAN SKRIPSI DI UNIVERSITAS MUHAMMADIYAH MALANG. In

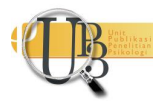


Undergraduate (S1) Thesis, University of Muhammadiyah Malang. http://eprints.umm.ac.id/44018/1/jiptummpp-gdl-qonitarohm-50562-1-qonitar-7.pdf

Saputra, M. R., \& Palupi, L. S. (2020, August). Relationship between Social Support and Psychological Well-Being of the Final Year Students. In E3S Web of Conferences (Vol. 202, p. 12027). https://doi.org/10.1051/e3sconf/202020212027

Sarafino, E. P., \& Smith, T. W. (2014). Health psychology: Biopsychosocial Interactions. John Wiley \& Sons.

Sulistyowati, M. (2016). HUBUNGAN SELF EFFICACY DENGAN STRES MAHASISWA YANG SEDANG MENGERJAKAN SKRIPSI. In Undergraduate (S1) Thesis, University of Muhammadiyah Malang. http://eprints.umm.ac.id/34417/1/jiptummpp-gdl-muliasulis-45634-1-mulia_2-9.pdf

Taylor, S. E. (2003). Health Psychology (Fifth ed.). McGraw Hill.

Taylor, S. E. (2009). Health Psychology (Eight ed.). McGraw Hill Inc.

Zakaria, D. (2017). Tingkat Stres Mahasiswa Ketika Menempuh Skripsi. Undergraduate (S1) Thesis, University of Muhammadiyah Malang. 